This is a postprint version. The definitive, peer-reviewed and edited version of this article Is published in Environment and Planning A, volume 46, issue 1, pages 203-221, 2014, DOI: 10.1068/a45718. Copyright (C) 2014 a Pion publication

\title{
Overcrowding and 'under-occupancy' in Romania: a case study of housing inequality
}

\section{Adriana Mihaela Soaita}

This paper examines aspects of space consumption in two very different housing types, the communist mid-rise estates and post-communist suburban self-built housing. Examining residents' perceptions in order to categorize space as overcrowded or under-occupied, the paper engages critically with the issue of the inefficient distribution of Romanian housing, that is a considerable mismatch between dwelling and household size. The analysis documents the continued salience of overcrowding in the communist estates and conversely, self-builders' satisfaction with the generous size of their new homes. Market forces permit various modes of residential mobility but their likely outcome is growing housing inequality while any redistributive impact will remain insignificant unless policy incentives could facilitate conversion of under-occupied space into (social) renting housing. However, only a sustained delivery of larger and affordable new dwellings could alleviate overcrowding.

Keywords: Overcrowding, housing inequality, space consumption, Eastern Europe, Romania.

How to cite:

Soaita A M, 2014, "Overcrowding and 'underoccupancy' in Romania: a case study of housing inequality" Environment and Planning A 46(1) 203 - 221 doi:10.1068/a45718 


\section{Introduction}

Overcrowding has been a major communist legacy in most post-communist countries however, in Romania - as in USSR, Albania and Poland - it reached extreme levels. Postcommunist population decline rather than new housing provision has improved habitable space indicators, but the stock distribution reveals a clear mismatch between dwelling and household size. Census data show almost equal shares of overcrowding and 'underoccupancy', each about $30 \%$, and a vacancy rate of $12 \%$. This inefficient housing distribution reflect many households' inability to meet their particular housing needs, as well as constraints in terms of stock characteristics (UNECE 2001). Past and current housing policies have obviously structured both terms, but so did more generally, the level of national economic development and degree of economic inequality.

While quantitative data allow precise analyses of the distribution of habitable space across available statistical units - both 'overcrowding' and 'under-occupancy' are politically loaded, economically structured and socio-culturally constructed concepts (Batten 1999). Conflict, inadequacy or unresponsiveness may arise between statutory definitions and households' perceptions or requirements, which at a more general level, connects with the social understanding of economic (in)-equality and the path-dependent nature of housing systems. Through a residents' lens, this paper examines the distribution of habitable space across two very different housing types, asking:

- What are the scale and the severity of overcrowding and 'under-occupancy' in Romania, particularly in the communist mid-rise estates and post-communist suburban, self-built housing?

- How do residents perceive their space standards and when do these qualify as severe overcrowding or under-occupancy? 
The political context of their advent - the rival paradigms of communism and democracy; command and market/informal economy - has marked their space and occupancy characteristics, as well as the housing expectations of their residents. Flats in the communist estates account for $70 \%$ of urban dwellings whereas suburban self-built houses are the largest post-communist addition, but account for only 6\% of the urban stock (NIS 2010). Overcrowding allegedly affects residents in the communist estates, but little is known to what degree, how this compares to past levels, or indeed how residents perceive their home space. Conversely, the suburban houses exhibit generous space standards, which raises interesting questions whether the availability of large habitable space may be categorized as 'underoccupancy'. Finally, to what extent can residential mobility within and across these submarkets balance the distribution of habitable space?

Excluding this introduction and conclusions, the paper has six sections. Section 2 briefly examines some major determinants influencing households' ability to occupy habitable space, and their characteristics in post-communist societies. Focusing on Romanian housing, Section 3 outlines the differential links between communist/post-communist housing policies and major housing types and examines current space consumption across urban-rural regimes and housing types. After an account of the methodology employed (section 4), three empirical sections follow. Section 5 measures the extent of overcrowding in sampled flats and houses. Section 6 analyses block residents' perceptions of their home space differentiating empirically between severe and relatively tolerable overcrowding. Section 7 examines self-builders' satisfaction with their spacious homes and questions whether large living space can be defined as under-occupancy.

\section{Space consumption}

The availability of habitable space, henceforth termed space consumption, features as a key constituent of wider housing concepts, such as conditions, occupancy, quality or systems 
(Mandic and Cirman, 2011). Perspectives centred on housing systems conceive the distribution of habitable space as a continuum having severely overcrowded dwellings at one end, and unoccupied dwellings at the other end, raising the issue of a mismatch between dwelling and household size. Tsenkova (2009:10) argued that the distributional (in)efficiency of housing systems, that is "the adequacy of supply relative to "need" is socially relevant and circumscribes policy recommendations worldwide. Vacancy/under-occupation denotes unsustainable use of resources whereas overcrowding hampers human development. This perspective may require critical reflection on the concepts of adequacy and need (Batten 1999; Bratt 2002), nonetheless, the emphasis on the public relevance of how space is under or over occupied cannot be ignored. Alternatively, a focus on dwellers shows the differentiated nature of space consumption in which homelessness, unconventional tenures and multiple homeownerships interlink dynamically with lifestyle preferences, lifecourse opportunities and broader processes of socioeconomic inequality. Besides economic fundamentals, the emphasis on the role of social institutions controlling the ways in which habitable space is differentially appropriated, in terms of tenure, income, race, gender or disability highlights pathways of socioeconomic and housing disparity (Clapham et al. 2012; Douglas 1991; Dunn 2000; Easterlow and Smith 2004; Imrie 2004; Mallett 2004).

If in simple terms, space consumption is a function of: a) the availability and characteristics of the historic and newly built housing stock at any one time and place; and b) households' ability to access it accordingly to their particular socioeconomic and demographic characteristics and preferences, it is clear that historic legacies and contemporary processes will determine distributional outcomes. First, pathways of socioeconomic development determine quantitatively and qualitatively the characteristics of housing stocks. This structural determinant was found to be the only major factor of the very different housing conditions across the enlarged EU (Mandic and Cirman 2011). In order to 
respond to changing household demand, housing supply should ideally consist of various dwelling types and show some degree of physical resilience to enable adjustment through residential mobility and/or in-situ conversion. More critically, supply availability should reasonably match demand spatially by regions, urban/rural regimes, settlements and housing type, and create some vacancy in order to enable chains of housing mobility.

On the demand-side, space consumption relates, on the one hand, to household changing socioeconomic and demographic characteristics and preferences. At the micro level, concepts such as lifecycle, lifecourse and lifestyle helped grasp the dynamics of matching dwelling characteristics with households' familial and occupational pathways (Clark 2012). On the other hand, households vary critically in their ability to convert needs into effective demand. The interplay between markets and public (housing) policies affects the nature of housing systems (Kemeny 1992), influencing the characteristics of housing stocks as well as households' choice, ability and means to access it, trading off between features of dwelling including habitable space - and other key housing aspects, such as location, neighbourhood characteristics and related amenities, tenure and financing. As the next section will briefly shown, the paradigmatic change in housing provision experienced by Eastern Europe has significantly influenced the determinants of space consumption. The section also aims to contextualise the Romanian case, which will be presented in Section 2.

\subsection{Determinants of space consumption in Eastern Europe}

Significant similarities between housing policies in the Eastern Bloc were conceptualised under the notion of the 'East European housing model (EEHM)' (Hegedus and Tosics 1992). The EEHM's centralised housing provision and allocation by state, enterprises or cooperatives predominantly involved urban housing within large estates, which currently account for $50-70 \%$ in most Eastern European cities. Given persistent shortages, many less privileged households had no other option but rural self-building within informal quasi- 
markets. Eligibility and occupancy restrictions and controlled residential mobility across places constrained access to state housing and self-building alike, and permitted limited choice even for the privileged (Sillince 1990).

The particular terms within and between these forms of housing provision varied considerably across countries and over time according to degrees of political centralization, institutional arrangements, urbanization policies and state commitment to housing. Only Czechoslovakia filled the quantitative housing shortage by 1989, whereas in the USSR, Albania, Poland and Romania overcrowding reached extreme levels. Reduced housing mobility linked lifecycle changes to space availability (Sillince 1990). Restricted ownership to one dwelling and relative socioeconomic egalitarianism resulted in low inequality in terms of space consumption, with notably more generous space standards only in rural Hungary and Yugoslavia where the state supported self-building during the 1980s. However, in terms of overall quality, housing inequality was noticeable between rural under-provided utilities compared to those in urban areas, among blocks within neighbourhoods, and between housing types (Szelenyi 1983).

Since 1989, the post-communist adoption of market mechanisms has resulted in multiple transitions, not only across places but across the economic, political and social domains (Sykora and Bouzarovski 2012). By 2011, the top-three economic winners Slovenia, the Czech Republic and Slovakia - had a GDP/capita of half the EU's average and still showed low levels of income inequality comparable to Sweden (Hungary showing similar trends). Conversely, Romania's and Bulgaria's GDP/capita was equivalently one-fifth whereas income inequality was higher than in UK (Lithuania and Latvia coming close, Eurostat 2012a). The dismantling of the EEHM through popular reforms of privatization to sitting tenants and, in some countries of restitution of housing and land, has been documented and questioned regarding its social fairness and the efficiency of resultant 'super-ownership' 
housing systems (Clapham et al. 1996; Fearn 2004; Lowe and Tsenkova 2003; Struyk 1996). Subsequent regulatory and financial mechanisms were introduced in order to address the inability of many households to run, maintain or access housing (Hegedus et al. 2012; Hegedus and Struyk 2005).

The extent to which the commodification of housing has enabled residential mobility, authentic choice and better occupancy standards appeared to be modest. For instance, during 2005-2010 the percentage of overcrowded population in Romania and Latvia only fell slightly, being currently the highest in the EU (55\%). Conversely, the Czech Republic showed the best performance in 2010 , with overcrowding falling from $33 \%$ to $22 \%$ over the period, becoming lower than in Italy and Greece but still twice the EU older states' average. In the remaining EU post-communist states, overcrowding fell moderately over the period, accounting for 35-49\% in 2010 (Eurostat 2012c). Lifecycle has remained a powerful determinant of overcrowding. Eastern Europeans aged under 18 are on average 2.5 times more likely to experience overcrowding than those aged over 65 . Affordability problems of young adults, who had to delay home leaving, contributed to unrelenting overcrowding (Mandic, 2008), but so did the legacy of a housing stock composed of many small dwellings. In the EU post-communist states, between $51-87 \%$ of all occupied dwellings had no more than three rooms and, on average, $91 \%$ of all occupied dwellings had no more than four rooms (Eurostat 2012b).

Additionally, new housing provision has only moderately improved after the steep decline during the 1990s. Constrained by underdeveloped housing finance, new provision has nonetheless added habitable space to the stock while contributing to socioeconomic housing differentiation. Speculative developers have targeted the wealthiest and filtered down to upper-middle income households once mortgages became available (Ourednicek 2007; Ruoppila and Kahrik 2003) whereas self-building has continued to produce numerous 
dwellings of different quality, varying degree of informality, and for a larger socioeconomic spectrum, most notably in south-eastern Europe (Deda 2003; Fehervary 2011; Stanilov 2007). However, the filtering effect of new provision through chains of residential mobility has not been clearly documented. Similarly, while population decline in the Baltic States, Romania and Bulgaria has continued - arguably relaxing housing pressures - and stabilized in the remaining EU post-communist states, other demographic changes have triggered an increase in the number of households and a drop in household size (EC 2011). However, the links between these changes, including those of migration, and residential mobility and space consumption require further research (Krisjane and Berzins 2012).

\section{Communist legacies and post-communist developments in Romania}

Communist-built housing currently account for $75 \%$ of the total, while only $14 \%$ and $11 \%$ date to pre- and post-communist periods, respectively (Figure 1). Legacies of communist policies act thus as significant structural factors on housing consumption today. Hence, this section looks at major forms of housing provision since 1945, which have prompted the striking difference between communist and post-communist major urban housing types, and

Figure 1. Dwelling stock by construction periods

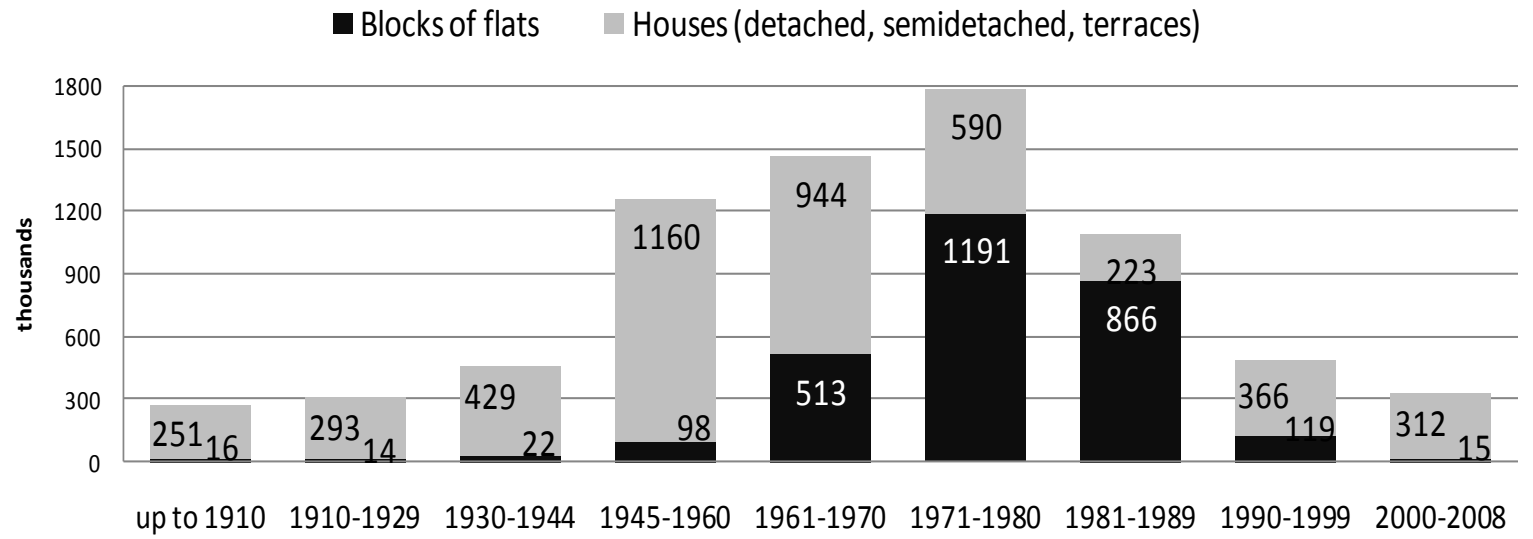

Source: NIS (2010) 
then examines habitable space distribution by rural-urban regimes and dwelling size.

Romanian housing provision varied between the first and last two decades of communist rule. During 1945-1969, individual households produced $80 \%$ of all new housing predominantly in villages and towns while state provision remained marginal (Sillince 1990). Currently, 2.4 million self-built houses date from this period. Constrains at the time of their construction - poor quality due to lack of subsidies, shortages of durable construction materials and lack of infrastructure - have largely persisted. Conversely, during the following two decades of communism, the state provided $84 \%$ of all new housing while self-building was severely discouraged and banned in cities. State housing consisted predominantly of small urban flats, located in exceptionally high-density, mid-rise estates whose residents, nonetheless, benefited from substantial subsidies or free entitlement and relatively good urban amenities and infrastructure (Sillince 1990). Currently, 2.7 million flats date from the communist period, accounting for $37 \%$ of total housing. Subsequent to post-communist privatization, they show a homeownership rate of $99.9 \%$ (NIS 2010).

Romanian new housing provision declined dramatically after 1989. The privatization of the construction sector and large-scale in-kind restitution of land to prior owners have considerably influenced access to, and the characteristics of new housing. Figure 2 shows that, by 2008, new housing provision was equally split across rural and urban areas; threequarters was privately financed. Privately financed housing consisted of a few speculative developments and a vast majority of dwellings self-developed, generally with cash (Budisteanu 2004). This reliance on black/grey economies was linked to self-built detached houses located predominantly in villages or in unplanned, un-serviced and unauthorised but lately legalized suburban settlements. Suburban housing has been a ubiquitous icon of socioeconomic and physical change (Fehervary 2011; Hirt 2012). Most suburban residents enjoy the status of a new housing class, nevertheless the contrast between these 'villas' and 
Figure 2. New housing provision

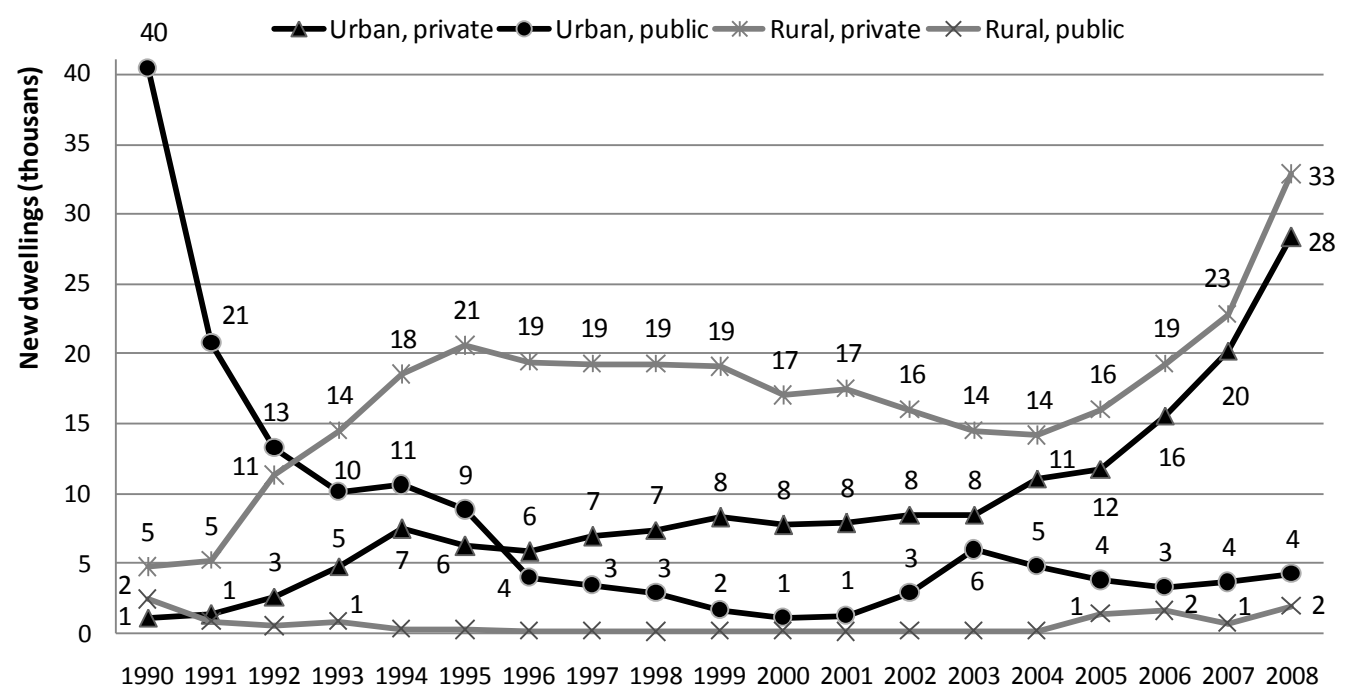

Source: NIS (2010)

the $27 \%$ of precarious new dwellings (of wattle-and-daub construction), mostly rural but also (sub)urban, illustrates a growing housing inequality, which has deepened inherited divisions within and between rural-urban worlds.

The publicly financed housing shown in Figure 2 refers to the early 1990s completion of the unfinished communist blocks and the outcome of post-2000 housing policy (MDRT 2012). Acknowledging the existence of pervasive housing problems, post-2000 governments have promoted a mix of demand/supply and explicit/implicit instruments in order to increase housing affordability and availability besides regulatory efforts to support a market-driven housing sector. On the supply side, output has remained relatively low. Excepting 2003, no more than 5,000 dwelling were built yearly by the National Housing Agency. Conversely, about 400,000 households have taken up subsidized housing saving schemes (5\% of total households) and some 50,000 first-time-buyers have taken guaranteed mortgages since 2007 (MDRT 2012). Additionally, subsidized thermal retrofitting of communist blocks has reached 180,000 flats by 2012 (7\% of all eligible units, MDRT 2012). Overall, post-2000 housing policy matches conceptualizations of fragmentation and pluralism (Yates 2012) by use of mix 
instruments and partnerships between governments, homeowners and other private actors. However, explicit support for housing totalled less than $1 \%$ of GDP, was predominantly directed to homeownership, and aimed to stimulate economic growth rather than to address social needs (Tsenkova 2009).

By 2012, low levels of housing construction and persistent housing immobility have not significantly amended the EEHM legacy in terms of housing characteristics, availability and occupancy though demographic change has moderately improved space indicators. Currently, there is no shortage of housing, except for specific categories (Pascariu and Stanescu 2003) and housing standards have improved (Table 1). Table 2 shows relatively similar space availability but a significant divide in terms of construction quality and infrastructure provision between rural and urban housing. Likewise, it documents that urban blocks, mostly built during communism, display poorer space indicators than houses but have kept their privileged utility provision. The number of dwellings consistently exceeds the number of households nationally, by counties and across housing types; this 'surplus' is lower in blocks than in houses. Among EU post-communist states, Romania displays, however, one of the poorest housing performances. Underprovided rural utilities placed Romania last in terms of housing quality (Tsenkova 2009). Likewise, Romania shows the lowest habitable space availability and the second highest overcrowding level (Eurostat 2012b, 2012c).

\subsection{The distribution of habitable space}

Classic macro-scale indicators, as presented in Table 1 and 2 were considered acceptable measures of space distribution (Tsenkova 2009) but they have limited power in analysing outcomes across socioeconomic groups and housing types, or connect to residents' meanings. From a micro-perspective, policy documents advocate the Bedroom Standard, which broadly recommends a separate bedroom for any married couple or person aged over 18 (Batten 
Table 1. Housing development

\begin{tabular}{|c|c|c|c|c|c|c|c|c|c|}
\hline & Households & Dwellings & $\begin{array}{c}\text { Dwellings/ } \\
1,000\end{array}$ & $\begin{array}{c}\text { Area /person } \\
\left(\mathrm{m}^{2}\right)\end{array}$ & Persons/room & $\begin{array}{l}\text { Persons/ } \\
\text { household }\end{array}$ & $\begin{array}{l}\text { Rooms/ } \\
\text { dwelling }\end{array}$ & $\begin{array}{l}\text { Public } \\
(\%)\end{array}$ & $\begin{array}{l}\text { Vacancy } \\
(\%)\end{array}$ \\
\hline 1992 & $7,251,635$ & $7,621,309$ & 336 & 11.6 & 1.2 & 3.1 & 2.5 & 21 & 4.6 \\
\hline 2002 & $7,315,891$ & $8,107,114$ & 380 & 14.3 & 1.0 & 2.9 & 2.6 & 2 & 11.6 \\
\hline
\end{tabular}

Table 2. Housing conditions in 2002

\begin{tabular}{|c|c|c|c|c|c|c|c|c|c|c|c|}
\hline & Households & Dwellings & $\begin{array}{c}\text { Dwellings/ } \\
1,000\end{array}$ & $\begin{array}{l}\text { Area /person } \\
\quad\left(\mathrm{m}^{2}\right)\end{array}$ & $\begin{array}{l}\text { Persons/ } \\
\text { room }\end{array}$ & $\begin{array}{l}\text { Rooms/ } \\
\text { dwelling }\end{array}$ & $\begin{array}{c}\text { Vacancy } \\
(\%)\end{array}$ & $\begin{array}{l}\text { Of wattle-and- } \\
\text { daub }(\%)\end{array}$ & $\begin{array}{l}\text { Water } \\
(\%)\end{array}$ & $\begin{array}{c}\text { Sewage } \\
(\%)\end{array}$ & $\begin{array}{l}\text { Gas } \\
(\%)\end{array}$ \\
\hline Rural & $3,359,465$ & $3,847,540$ & 377 & 14.2 & 1.0 & 2.7 & 15.0 & 44 & 16 & 15 & 8 \\
\hline $\begin{array}{l}\text { Urban, } \\
\text { of which: }\end{array}$ & $3,956,426$ & $4,259,574$ & 382 & 14.3 & 1.1 & 2.4 & 8.6 & 8 & 89 & 89 & 76 \\
\hline Blocks & $2,800,545$ & $3,021,122$ & - & 13.8 & 1.0 & 2.3 & 8.1 & 0 & 100 & 100 & 87 \\
\hline Houses & $1,133,858$ & $1,213,051$ & - & 15.5 & 1.0 & 2.8 & 9.6 & 27 & 63 & 60 & 49 \\
\hline
\end{tabular}

Source: NIS ( 2012) 
Table 3. Minimal SSOS (Housing Act, 1996)

\begin{tabular}{rrrrrrrrrr}
\hline Persons/household & 1 & 2 & 3 & 4 & 5 & 6 & 7 & 8 \\
\hline Habitable rooms & 1 & 2 & 3 & 3 & 4 & 4 & 5 & 5 \\
\hline
\end{tabular}

1999; EC 2011). Statutory space and occupancy standards (SSOS) are usually less generous. Although they tend to concern all new/newly-refurbished housing, it is clearly difficult to be applied retrospectively or enforced post-construction (Goodchild and Furbey 1986). In Romania, the Housing Act (RG 1996) regulates minimal SSOS for new dwellings in terms of minimal number of habitable rooms, which includes bedrooms and a living room (Table 3) and floor-area by household size. In terms of room requirements, current standards equal preceding communist allocation norms - in many instances falling below the Bedroom Standard - whereas floor-area specifications have increased by $20 \%$. These standards provide an indicative basis for a preliminary analysis of the changing distribution of habitable space. This will be later contrasted to residents' perspectives.

Census data from 1992 and 2002 demonstrate a slight improvement of space distribution. Overall, 1.5 million less people lived in, and half million less dwellings were occupied below or equal to minimal standards. Vacancies increased, which counterbalanced quantitatively the net addition to the housing stock over the decade (Figure 3). These significant vacancy rates comprised a low permanent vacancy rate (1\%) in both urban and rural areas, whereas second/seasonal dwellings accounted for $8 \%$ and $14 \%$, respectively. This shows increasing housing differentiation through the route of multiple homeownerships.

Overall, one-third and one-quarter of the occupied urban and rural stock, respectively were over-occupied, housing 10 million persons, of whom almost 3 million persons consumed less than $6 \mathrm{~m}^{2}$ habitable space ( 1 million in cities) and other 3 million persons 
Figure 3. Space distribution according to minimal SSOS

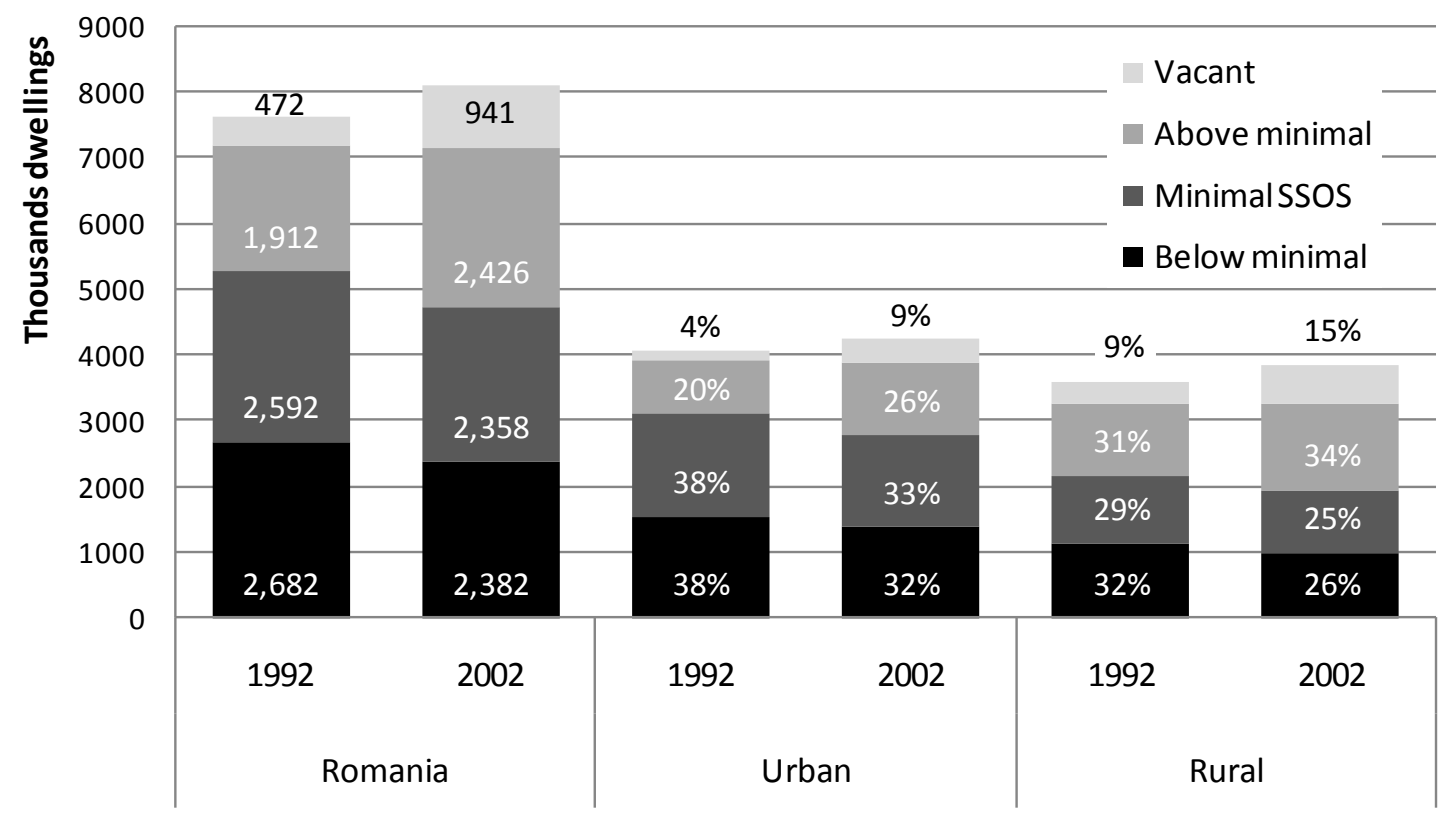

Source: NIS (2012)

consumed between $6-8 \mathrm{~m}^{2}$ (half in cities). Conversely, 5 million persons lived above minimal standards, slightly more in rural than urban areas. These asymmetries indicate a mismatch between household and dwelling sizes. Data indicate smaller odds for rural than urban dwellings to be overcrowded but higher odds for rural than urban dwellers to experience extreme overcrowding.

Regarding urban housing, Figure 4 shows that among one/two-roomed dwellings, which constitute $60 \%$ of total, about half were over-occupied. High vacancy rates resulted in an actual decrease in the occupied units. Conversely, space consumption above minimal standards was spread across all dwellings, being preponderant only in the minority of dwellings larger than three rooms. During 1992-2002, occupancy levels improved in all but one-roomed dwellings. About 1 million less urbanites lived in, and 170,000 less dwellings were occupied below minimal standards; this represented an improvement slightly superior than in rural areas. Regrettably, the available data does not allow finer analysis by regions nor housing types. Therefore, fieldwork was conducted in order to examine issues of 
Figure 4. Urban housing: space consumption by dwelling size

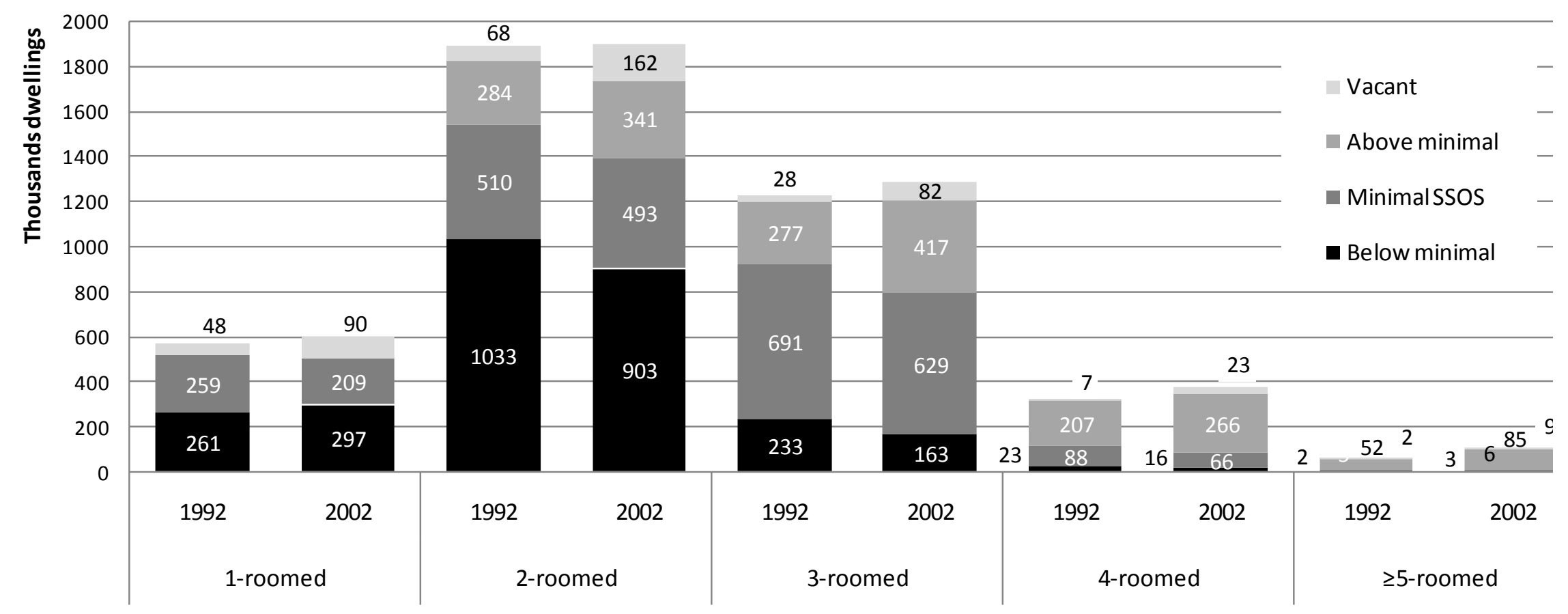

Source: NIS (2012) 
overcrowding and 'under-occupancy' through a residents' lens - as well as to explore more generally current housing problems and residents' responses (Soaita 2010) - in communist estates and post-communist self-built suburban housing. The next section will briefly introduce the selected case study and some methodological considerations.

\section{The case study}

The city of Pitesti (170,000 inhabitants) was chosen for its portrayal of a typical 'socialist city' (Andrusz et al. 1996) in terms of massive post-1948 urban and industrial growth, and a high dominance of state housing. Among the eight large Romanian cities that grew faster than average during communism, seven were also strong new industrial centres (Ronnas 1984). While any of these would qualify, the research benefited from local knowledge and access as Pitesti is the city I lived and worked in for 15 years. Communist flats accounted for $89 \%$ of total housing stock in these cities and $92 \%$ in Pitesti (totalling 54,000 flats). Pitesti's post-communist trajectory benefitted from an above national average of foreign direct investment, thus becoming a 'successful' second-tier city within the national network (Benedek 2006). As in most Romanian cities, suburban housing commenced during the early 1990s in unplanned, barely accessible locations and accelerated towards the end of the decade, sustained by economic growth, regularization policies and utility development. Suburbanization doubled the built-up area of Pitesti (Figure 5) and by 2008 accounted for about 4000 houses; these, together with 2000 houses located in adjacent rural administrations, represented $6 \%$ of the housing stock. Utility development was uneven but most self-builders reached self-sufficiency by means of wells for drinking water, sewage tanks and alternative heating systems (Soaita 2013).

The mixed nature of the research determined the choice for a 'typical neighbourhood' as a subunit of analysis for systematic quantitative sampling and in-depth observations and interviewing. Finally, one reasonably typical communist housing estate and three 
Figure 5. The city of Pitesti

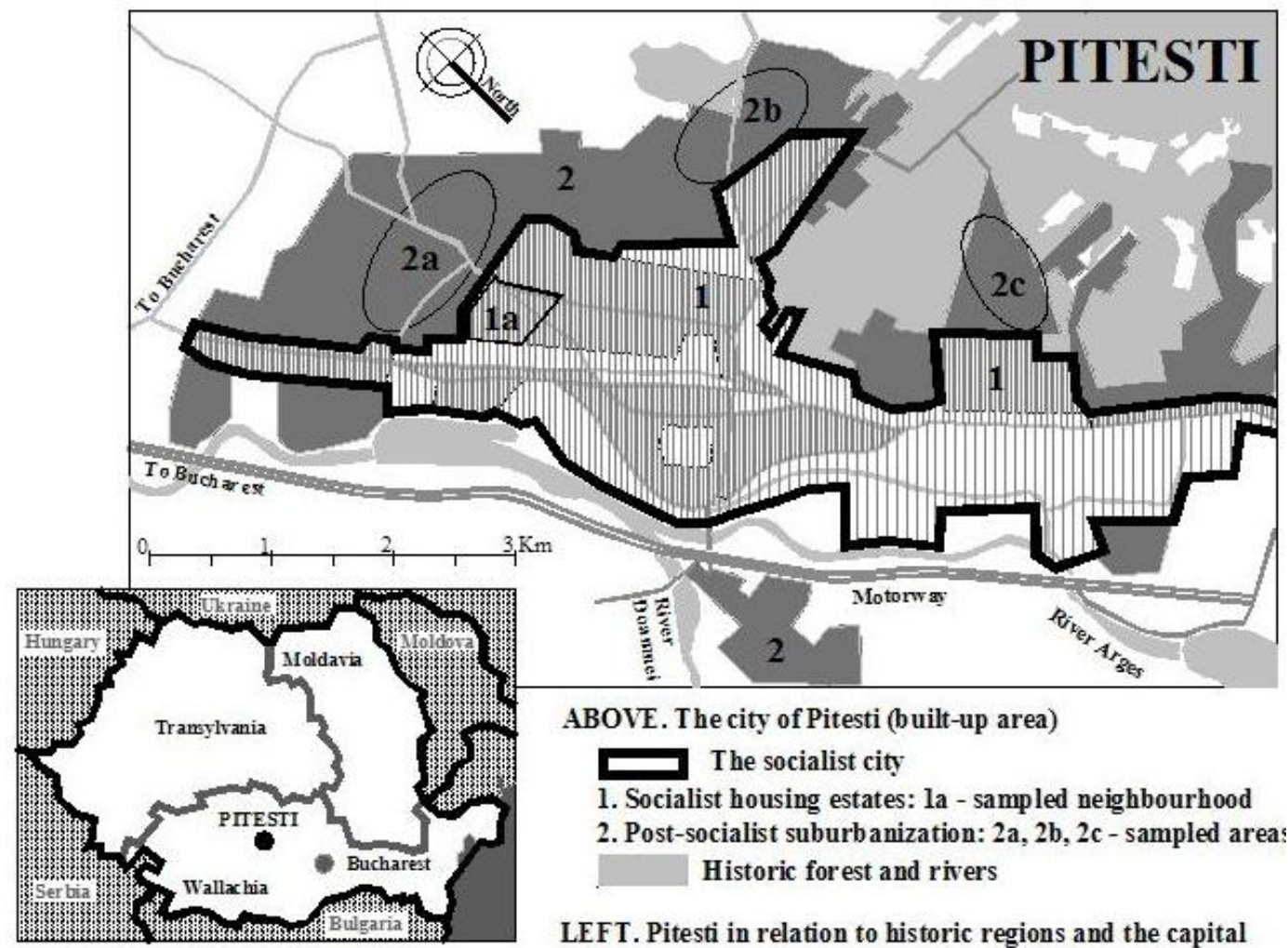

Source: author's graphics

Figure 6. General views
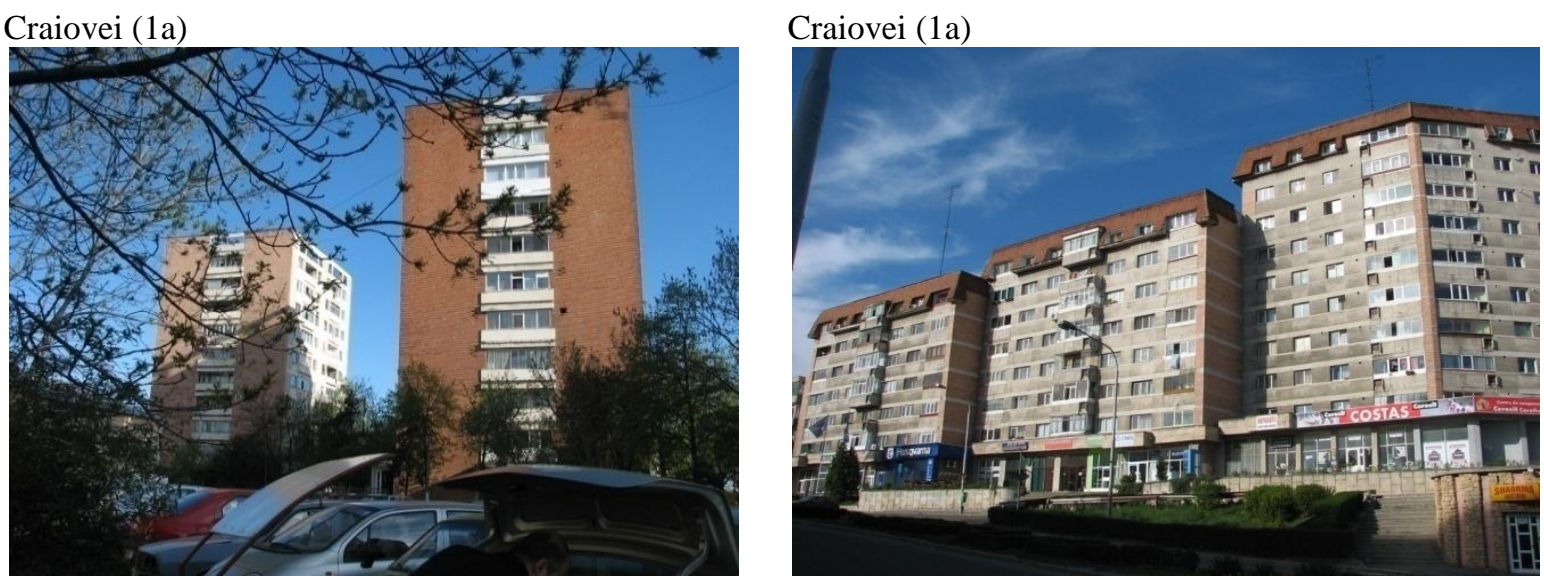

Suburbs ( 2b)

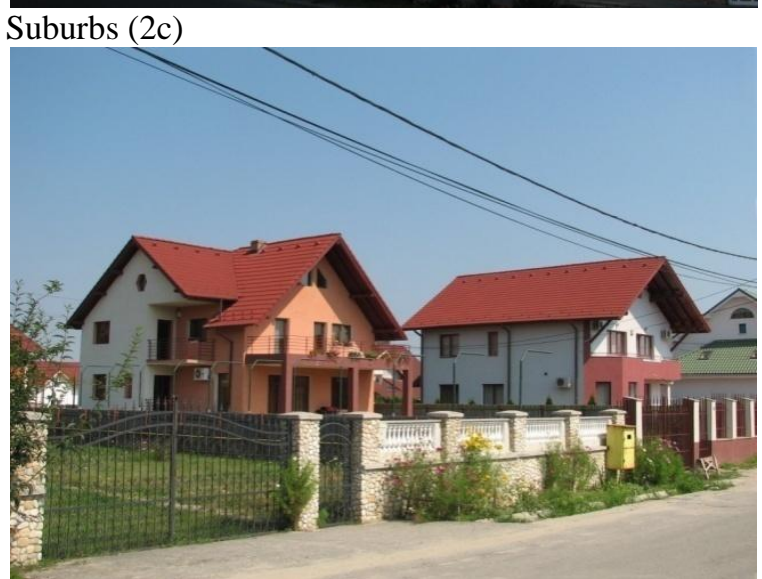

Source: author's collection (2008) 
representative suburban areas were selected for analysis (Figure 5 and 6). Among the 15 large housing estates in the city, the selected Craiovei neighbourhood (5,100 flats) is reasonably comparable to all except three neighbourhoods, of which two have retained a lower socioeconomic status whereas the central estate has always enjoyed a privileged position.

From September 2007 to January 2008, I collected a carefully stratified sample of 150 questionnaires based on characteristics of blocks and flats. Approaching residents by ringing the doorbell proofed unfeasible ( $80 \%$ non-response rate) therefore, I had to resort to sampling residents systematically near their block (39\% refusal rate).

Within the eight partially merged suburban developments, about a quarter of houses were permanently inhabited. I selected three neighbourhoods - in terms of environmental attractiveness and stage of development in order to reach a reasonably representative sample for the city - comprising roughly 1,000 plots. From December 2007 to June 2008, I collected 100 questionnaires by approaching residents 'over the fence' on each street in every other fifth plot (replaced by the next when required; 33\% refusal rate). Considering sampling limitations, quantitative data was used with caution alongside the qualitative data in order to enhance understanding but it remains nonetheless important since comparable information is nonexistent. The 91 block residents and 59 self-builders who further agreed to be interviewed in-depth were shortlisted according to key socioeconomic characteristics and housing histories. Finally, 24 in-depth interviews were held in each housing type, which involved 28 block residents and 32 self-builders.

\subsection{Participants'profiles}

Table 4 and 5 present a summary socioeconomic profile of the quantitative samples contrasted to national averages. The legacy of privileged allocation of state housing has persisted. Block residents were better educated and more affluent than national averages. But self-builders were significantly better educated and more affluent than block residents, which 
Table 4. Sociodemographics

\begin{tabular}{ccccccc}
\hline & \multicolumn{3}{c}{ Education (\%) } & \multicolumn{3}{c}{ Household composition } \\
\cline { 2 - 7 } & $\begin{array}{c}\text { Primary/ } \\
\text { gymnasium }\end{array}$ & Secondary & $\begin{array}{c}\text { University and } \\
\text { over }\end{array}$ & $\begin{array}{c}\text { Persons } \\
\text { (median) }\end{array}$ & $\begin{array}{c}\text { Single-person } \\
(\%)\end{array}$ & $\begin{array}{c}\text { Extended } \\
\text { families }(\%)\end{array}$ \\
\hline Blocks & 8 & 59 & 33 & 2 & 23 & 12 \\
Houses & 1 & 33 & 66 & 4 & 6 & 19 \\
$\begin{array}{c}\text { National } \\
\text { average* }\end{array}$ & 41 & 46 & 9 & 2.9 & 17 \\
\hline
\end{tabular}

*Source: NIS (2005)

Table 5. Household income (percentages)

\begin{tabular}{cccc}
\hline & Not /just enough to live on & $\begin{array}{c}\text { Enough to live decently without } \\
\text { affording expensive goods }\end{array}$ & $\begin{array}{c}\text { Enough to buy some/all } \\
\text { expensive goods needed }\end{array}$ \\
\hline Blocks & 42 & 32 & 25 \\
Houses & 11 & 34 & 53 \\
National \\
average*
\end{tabular}

*Source: Badescu et al (2007)

indicates the socioeconomic inequality between these housing types. Considering the dominance of communist flats in the local market, it is not surprising that $80 \%$ of sampled self-builders had moved from blocks. This confirms other scholarly observations that housing estates have slowly lost status through outmigration (van Kempen et al. 2005). Dwelling sizes and market values across the samples were remarkably dissimilar. Among flats, $65 \%$ were under $50 \mathrm{~m}^{2}$ and $71 \%$ were one/two-roomed. Two-thirds of block residents bought their flats as sitting tenants, while one-third purchased in the market. The 2008 value of a one-/two/three-roomed flat was about $€ 30,000 / € 60,000 / € 80,000$, respectively. Conversely, only 14 self-builders were restitution claimants, the remaining having bought land. Rarely sold on, a median-sized plot $\left(800 \mathrm{~m}^{2}\right)$ with a median-sized house $\left(175 \mathrm{~m}^{2}, 5.5\right.$ rooms $)$ - on average built in six years, normally mortgage-free - would be estimated at $€ 370,000$ (Soaita 2013). 


\section{The extent of overcrowding}

Tables 6 shows that, in terms of habitable rooms per household size, block residents were significantly more likely than self-builders to live below or equal to the Romanian minimal SSOS. The housing distribution within the sampled flats mirrors the national pattern: $28 \%$ and $32 \%$ were occupied above and below the minimal levels, respectively. There was strong evidence to suggest that overcrowding in the blocks was a structural phenomenon rather than strictly a problem of affordability. The most important factor was dwelling size. One/tworoomed flats were 18 times more likely to be overcrowded than larger flats. The second most important factor was lifecycle. Sampled block residents with children were 8 times more likely to experience overcrowding than those without. Similarly, economically active block residents were 3 times more likely to experience overcrowding than pensioners.

Interestingly, no significant differences in households' economics or satisfaction with the flat were found between overcrowded and non-overcrowded sampled participants. The former confirms the structural foundations of overcrowding in the communist estates discussed above whereas the later suggests an acknowledgement of these particular and additional, wider constraints within the housing system (outlined in section 2) as well as likely higher overcrowding levels experienced before. Subsequent comparative analysis of participants' current and previous space standards revealed that in both samples overcrowding had significantly decreased. For self-builders it fell from $20 \%$ - which was, however, much lower than the national average - to nil while for block residents it fell from $49 \%$ to $32 \%$. In terms of floor area, it is not surprising that almost all block residents (94\%)

Table 6. Space consumption in terms of number of rooms

\begin{tabular}{cccc}
\hline & Above minimal & Minimal SSOS & Below minimal \\
\hline Blocks & 28 & 40 & 32 \\
Houses & 94 & 6 & nil \\
\hline
\end{tabular}


lived below the minimal standards given that communist flats are smaller by $20 \%$ (a few by $50 \%$ ) than current SSOS. Conversely, $94 \%$ of sampled self-builders substantially increased their space standards given that houses were on average 4-5 times larger than flats. However, how closely do these SSOS mirror residents' perceptions of their habitable space and what are residents' meanings of severe overcrowding and under-occupancy?

\section{Space as a problem: the blocks of flats}

The 28 block residents interviewed were occupying their flats in excess of, equal to, or below the minimal SSOS and their narratives varied accordingly. However, they perceived the inflexible layout of their undersized flats as inappropriate even when they benefited from an extra habitable room than minimal thresholds:

"Rooms are satisfactory large, although, if just a little bit larger... I had a space problem when I bought my bike. I couldn't keep it on the balcony as its muddy wheels had to cross the lounge. It was a nuisance in the lobby, which is really small. Bikes should stay somewhere in the basement, in a communal space, in a garage, not in the flat! I am not married, that's why the space seems enough. Practically even a washing machine is hard to fit!" (male aged 47; 1-person/2-rooms).

Generally, participants considered tolerable the minimal SSOS in terms of number of rooms (40\% in the quantitative sample). Nonetheless, this seemed inappropriate or even disturbing when parents lived together with adult children:

"We have three bedrooms and two children. This was quite luxurious! Now children grew adults. Our daughter just got married. They had to stay with us. I personally take pride that they aren't dissatisfied with this arrangement. We try not to disturb them... everyone minds one's own business. Yet, how can we not step on each other's toes when we all collate in the bathroom?" (male aged 68; 5-persons/4-rooms). 
Conversely, shortage of rooms below minimal SSOS was perceived as severe overcrowding (32\% in the quantitative sample) and mostly affected families with children. Housing policies for young families target first access to housing rather than family cycle. Natalia (aged 32) moved from the Republic of Moldova and noticed that Romanian flats were smaller than their Soviet counterparts (relatively inconsistent data indicate they might be the smaller in the exEastern Bloc, Sillince, 1990):

"It's small, small! That's the only reason - as I like the flat - that makes me... insist, to say so, to my husband! Look, my baby clothes are on the floor, and they shouldn't stay there, but there is no room in the wardrobe! I think this bedroom, this living room, are sufficient for a childless couple! When a child is born, it's extremely small! We have two children, so believe me, if we buy a new toy there is no space to put it! It is small, the flat is small! There is no room for two persons in this kitchen!" (4persons/2-rooms).

Participants clearly preferred flats that give separate access to each room from the hallway against bedrooms accessed only through a living room - because often living rooms function as bedrooms. The most dramatic experience of overcrowding comes from a resident in a 'reduced-comfort' flat (50\% smaller than current SSOS). Such flats were built nationwide during the 1960s and 1970s and, despite their unpopularity, were still rapidly privatised:

“This dwelling, which inappropriately we call 'home', has two rooms and no more than $35 \mathrm{~m}^{2}$. The layout is inapt, wagon-style, its living room - as we indulgently call it - is just 4.3 by 3.3 metres. Awfully undersized! When our child was born, we discovered its functional faults. Imagine a child who must pass through your room to get to the bathroom, or you through his room. Evidently, we preferred to disturb him than him catching us in intimate moments. We felt pressured by the scarcity of living 
space, by the paucity of human-like living conditions!" (male aged 54, 2-persons/2rooms).

On the one hand, market rigidities of a large stock of comparable flats and depressed levels of new provision produced a peculiar Romanian real-estate bubble in this submarket. The value of a built square metre rose about $50 \%$ annually since 2000 and resulted in 2008 in an average increment of about $€ 20,000$ to move up to an extra room. Given the average declared household income, the affordability figure for an extra room equated to 4-5 times annual income, making it difficult for most residents to move up, yet enabling a few to release equity by moving out, generally into secondary rural homes. On the other hand, the smallness of flats provided no incentive for those 'under-occupying' households to downsize, since they still perceived the space as scarce. In fact, in order to converge to minimal SSOS, the neighbourhood still needed to shed residents. While block neighbourhoods are more likely to remain largely overcrowded, the following section examines self-builders' satisfaction with their homes' generous space and questions whether this may qualify as 'under-occupancy'.

\section{Space as a gain: self-built housing}

Out of 24 interviews, 12 involved participants who inhabited their newly built houses, having moved out of owned flats; 10 were still living in owned flats while building; and the remaining two were unusual cases. The Mincu family (5-persons/3-generation) have always lived in a tiny bungalow, self-built during communism at the far edge of the city. They were currently building a small two-story house on the same plot for when Radu, aged 20, starts his family. Conversely, Mrs Podescu has been unusually mobile. She moved out of her urban flat into a newly self-built rural house, while in 2008 she was building three suburban houses in the vicinity, for herself and her two adult children. Eight participants had previously experienced (severe) overcrowding. The Constantinescu family, (5-persons/3-generation) 
chose to sell their three flats and rent temporarily a two-roomed flat in order to finance their new spacious home, as Maria (aged 33) explained:

"Eh, how shall I say? I took my children few times to the house and they said 'what is this, mum? This is the house you told us about? But mum, this is not a house, it is a block!' I said 'Yes, indeed, it's a block' 'But mum, is it as big as our block where we live?' 'Darling, it's half our block!' 'Mum, how many rooms we will have? Each one a room, isn't it?' I said, yes, darling, one room. 'Oh, only one room in this huge house? Yes, darling, just one room. 'Will grand-ma' stay with us in the house?' Yes, she would stay with us in this house. 'Will she also have many rooms?' Yes, she will!" (floor area over $300 \mathrm{~m}^{2}$ ).

Self-building allowed for personalisation of layouts and extended-family inhabitation. Satisfaction with large indoor space was reinforced by contentment with gardens, which became a symbol of this new lifestyle. However, while gardens seemed a gain in absolute terms, there was a downside to large interior space. Construction costs were never mentioned as problems - a peculiarity of self-building which can compensate for costs by ceaselessly extending construction time - but maintenance and especially the cost of heating were, particularly by participants who built very large houses during the 1990s, when construction materials and utility costs were relatively low:

"Every space is huge! A hallway of $50 \mathrm{~m}^{2}$ ! And I was coming from a two bedrooms flat of $46 \mathrm{~m}^{2}$ An aberration! A living room of $60 \mathrm{~m}^{2}$ ! Do you know how much it costs me the heat? The architect should have told me 'buddy, you're crazy'! What shall we do now? It became a too big a load, a load we cannot carry!" (couple aged 55 and 59, 3-persons household/floor area over $500 \mathrm{~m}^{2}$ ).

Despite the household's noticeable affluence, these concerns were a major theme in our three hour interview. Participants highlighted the circularity of the argument. Space as a problem in 
their previous dwelling, a flat, was addressed by generous self-built standards but ultimately this turned out to be a major problem of affordability, which had to be addressed:

"I do not know, please believe me, what shall I do with this house! Shall I thermallyinsulate it? Shall I build a smaller one in the garden, an ideal two bedrooms cosy house? I am 59 years old, is it worth to start all over again? One neighbour had divided his house into flats and sold them out. Another neighbour gave me the idea to down-size in the kitchen during winters!"

This apprehension gives empirical grounds to characterize under-occupancy as instances of households occupying large dwellings while facing difficulties in affording construction, running or maintenance costs. As shown above, market forces permit various modes of downsizing to adjust under-occupancy in self-built housing. Obviously, a strategy of seasonal downsizing to one/few rooms will not contribute to balance space consumption. Yet, this seemed to remain the preferred option and even a reason to build, a point surprisingly emphasised by the least affluent self-builders:

"I've seen how people in blocks were thrown out on streets because they couldn't afford to pay the bills. I said 'God, help us never get there'. If we had no money, if we remained jobless and couldn't afford to pay the bills, we might get disconnected! Yet, we live in our own house, even if in only one room!" (female aged 63).

Conversely, subdividing in order to sell or rent, or moving out will contribute to the diversification of the housing stock and facilitate residential mobility. Yet, it remains very unlikely that self-builders' downsizing strategies would directly contribute to the alleviation of severe overcrowding among block residents unless governments embark on empowering less affluent and larger households to move up within private rental housing. 


\section{Conclusions}

This paper aims to assess the scale and severity of overcrowding and 'under-occupancy' in Romania, particularly in communist housing estates and post-communist suburban, self-built housing as well as to explore how residents perceived the availability of habitable space. According to nationally recommended standards, the Romanian population suffering overcrowding accounts for a significant $46 \%$ of the total (or $55 \%$ according to the Bedroom Standard). The analysis revealed significant and comparable national and urban shares of dwellings occupied below and above minimal standards, which corresponded to the space distribution among the sampled block residents. Data indicated higher odds for urban than rural dwellings to be overcrowded but conversely smaller odds for urban than rural dwellers to experience extreme overcrowding.

Block residents categorized any shortage of habitable rooms below minimal standards as intolerably severe overcrowding. When the number of rooms corresponded to minimal standards but floor area fell short - in other words, there was shortage of space - residents viewed this as tolerable overcrowding. Accordingly, 94\% of sampled block residents lived in overcrowded flats, but one-third suffered severe overcrowding, notably families with children. This was clearly a structural legacy of the housing stock, which comprises a large majority of undersized flats with just one/two rooms. Common affordability problems of young adults to access independent housing were aggravated by particularly high vacancy rates within one-roomed urban dwellings $(15 \%)$. The generous size of self-builders' homes stood out from that of flats, matching only $4 \%$ of the national housing stock. Self-builders' satisfaction with their new, very comfortable lifestyle was thus unsurprisingly high. Residents' narratives clearly highlighted the affordability criteria for distinguishing the availability of large space from under-occupancy. Under-occupancy thus refers to households occupying large dwellings while facing severe difficulties in affording housing 
running/maintenance costs, or concluding the construction process. In this case study, $94 \%$ of sampled self-builders lived very comfortably but a few were undeniably under-occupying their homes.

Finally, can market-lead housing mobility within and across these submarkets balance the distribution of habitable space? While the cornerstones of a regulatory framework that enable a market-oriented housing system seem adequate (Tsenkova, 2009), the new markets have built on past legacies, not only in terms of inherited physical characteristics, occupancy and deficits of housing stocks, but also in the reactivation of historic structures and traditional forms of housing provision. The communist housing estates of (extremely) overcrowded flats exemplify the former, where space consumption has only slightly improved over the last two decades via demographic changes rather than residential mobility. The new land markets and the informal economies of self-building, which besides self-builders' financial capital have enabled generous space consumption in large suburban homes as a case of social rather than strictly residential mobility, illustrate the latter.

It seems highly unlikely that housing mobility within communist estates can alleviate the problem of severe overcrowding even if affordability improves due to the widespread shortage of space in these undersized flats, which creates no incentives to downsize unless circumstances impose it. Housing mobility across housing types was mostly unidirectional. Mobility from blocks towards self-built housing was substantial in this case study and a few households temporarily embarked on severe overcrowding as a strategic route to finance their new homes. Conversely, the few under-occupying self-builders preferred passive strategies to downsize seasonally to fewer rooms. Market forces permit various modes of changing the parameters of space consumption within, between and beyond these housing types - by means of residential mobility, stock adaptation and new provision - but their likely outcome is the translation of economic into housing inequality. Conversely, any redistributive impact 
will remain insignificant unless policy incentives could facilitate conveying under-occupied space into (social) rented housing.

First, a mix of incentives/disincentives should aim both to bring vacant stock into (rental) markets and to support downsizing. The former requires revision of the regulatory framework for rental housing whereas the latter needs a more liberal revision of current SSOS, which seem merely tolerable. Second, via a mix of planning policies, tax exceptions and technical support, local governments and state inspectorates should facilitate the conversion of very large houses into flats and conversely, of very small flats into larger ones. Third and most decisively, since only a sustained delivery of medium-sized and affordable new (social) dwellings could clearly alleviate overcrowding in Romania, governments should try to stimulate economic growth while continuing to facilitate low/lower-middle income households' access to housing. Finally and more generally, this paper draws attention to the rising housing inequality in Romania due to growing economic inequality and different household's ability to engage in economic informality. As the accumulation of housing wealth has increasingly been relied upon within EU social policies, including as a convertible resource into cash (Doling and Elsinga, 2013), there is a need to analyse critically the limits and broader consequences of this approach within the post-communist 'super-ownership' states where, for most residents, adequate housing has yet to be achieved.

\section{Acknowledgements}

I thank Prof Chris Hamnett, King's College London, and the three anonymous referees for their valued input.

\section{References}

Andrusz G, Harloe M, Szelenyi I, eds. 1996 Cities after Socialism: Urban and Regional Change and Conflict in Post-Socialist Societies (Blackwell: Oxford) 
Badescu G, Comsa M, Sandu D, Stanculescu M, 2007 Barometrul de Opinie Publica Octombrie 2007 (Fundatia Soros: Bucharest)

Batten DC, 1999, "The mismatch argument: the construction of a housing orthodoxy in Australia" Urban Studies 38(1) 137-151

Benedek J, 2006, "Urban policy and urbanisation in the transition Romania" Romanian Review of Regional Studies 2(1) 51-64

Bratt RG, 2002, "Housing and family well-being" Housing Studies, 17(1) 13-26

Budisteanu I, 2004, "Long-implications of the housing finance arrangements" The Eastern European Workshop on Housing Finance and Housing Affordability Budapest

Clapham DF, Hegedus J, Kindrea K, Tosics I, Kay H, eds. 1996 Housing Privatization in Eastern Europe (Greenwood Press: London)

Clapham DF, Clark WAV, Gibb K, eds. 2012 The SAGE Handbook of Housing Studies (SAGE: London)

Clark WAV, 2012, "Residential mobility and the housing market", in The SAGE Handbook of Housing Studies Eds. DF Clapham, WAV Clark, K Gibb (SAGE: London) pp 66-83

Deda L, 2003, "The new housing market in Tirana", in Housing Change in East and Central Europe: Integration or Fragmentation? Eds. S Lowe, S Tsenkova (Ashgate: Aldershot) pp 171-180

Doling J, Elsinga M, 2013 Demographic Change and Housing Wealth: Home-owners, Pensions and Asset-based Welfare in Europe (Springer: London)

Douglas M, 1991, "The idea of a home: a kind of space" Social Research 58(1) 287-307

Dunn JR, 2000, "Housing and health" Housing Studies 15(3) 341-366

Easterlow D, Smith SJ, 2004, "Housing for health: can the market care?" Environment and Planning A 36(6) 999-1017

EC, 2011 Key figures on Europe European Commission (EU Publications: Luxembourg) 
Eurostat, 2012a, "Distribution of income (ilc_di). Gini coefficient" http://appsso.eurostat.ec.europa.eu/nui/show.do?dataset=ilc_di12\&lang=en

Eurostat, 2012b, "Occupied conventional dwellings by number of rooms and occupants" http://appsso.eurostat.ec.europa.eu/nui/show.do?dataset=cens_01ndnbown\&lang=en

Eurostat, 2012c, "Overcrowding rate by age, gender and poverty status - Total population" http://appsso.eurostat.ec.europa.eu/nui/show.do?dataset=ilc_lvho05a\&lang=en

Fearn J, ed. 2004 Too Poor to Move, Too Poor to Stay: A Report on Housing in the Czech Republic, Hungary and Serbia (OSI: Budapest)

Fehervary K, 2011, "The materiality of the new family house in Hungary: postsocialist fad or middle-class ideal?" City \& Society 23(1) 18-41

Goodchild B, Furbey R, 1986, "Standards in housing design: a review of the main changes since the Parker Morris report (1961)" Journal of Property Research 3(2) 79-99

Hegedus J, Lux M, Teller N, 2012, eds. Social Housing in Transition Countries (Routledge: London)

Hegedus J, Struyk RJ, eds. 2005 Housing Finance: New and Old Models in Central Europe, Russia and Kazakhstan (OSI: Budapest)

Hegedus J, Tosics I, 1992, "Housing reform in Hungary", in The Reform of Housing in Eastern Europe and Soviet Union Eds. B Turner, J Hegedus, I Tosics (Routledge: London, New York) pp 151-178

Hirt SA, 2012 Iron Curtains: Gates, Suburbs and Privatization of Space in the Post-Socialist City (Wiley-Blackwell: Pondicherry)

Imrie R, 2004 "Disability, embodiment and the meaning of the home" Housing Studies 19(5) 745-763

Kemeny J, 1992 Housing and Social Theory (Routledge: London, New York) 
Krisjane Z, Berzins M, 2012, "Post-socialist urban trends: new patterns and motivations for migration in the suburban areas of Riga, Latvia" Urban Studies 49(2) 289-306

Lowe S, Tsenkova S, 2003 Housing Change in East and Central Europe: Integration or Fragmentation? (Aldershot: Ashgate)

Mallett S, 2004, "Understanding home: a critical review of the literature" The Sociological Review, 52(1) 62-89

Mandic S, 2008, "Home-leaving and its structural determinants in western and eastern Europe: an exploratory study" Housing Studies 23(4) 615-637

Mandic S, Cirman A, 2011, "Housing conditions and their structural determinants: comparisons within the enlarged EU" Urban Studies 49(4) 777-793

MDRT, 2012, "Ministerul Dezvoltarii Regionale si a Turismului. Lucrari publice" (Bucharest: www.mdrt.ro)

NIS, 2005 Statistical Yearbook 2005 (National Institute of Statistics: Bucharest) http://www.insse.ro/cms/files/RPL2002INS/vol5/tablesdemo.htm

NIS, 2010 Statistical Yearbook 2010: Time Series 1990-2009 (National Institute of Statistics: Bucharest) http://www.insse.ro/cms/rw/pages/anuarstatistic2010.en.do NIS, 2012 Census 2002. Query public system RPL 1992and 2002 (National Institute of Statistics: Bucharest) http://www.insse.ro/cms/rw/pages/rpl2002.en.do

Ourednicek M, 2007, "New suburban development in the post-socialist city: the case of Prague" Geografiska Annaler B, 89(2) 111-126

Pascariu S, Stanescu M, 2003, "Management improvement and quality standard challenges: local government and housing in Romania", in Housing Policy: An End or a New Beginning? Ed. M Lux (OSI: Budapest) pp 245-291

RG, 1996, "Legea 114: Legea locuintei" in Monitorul Oficial 254 Ed. Romanian Government (Romanian Government: Bucharest) 
Ronnas P, 1984 Urbanization in Romania: A Geography of Economic and Social Change Since Independence (Stockholm School of Economics: Stockholm)

Ruoppila S, Kahrik A, 2003, "Socio-economic residential differentiation in post-socialist Tallinn" Journal of Housing and the Built Environment 18(1) 49-73

Sillince J, ed. 1990 Housing Policies in Eastern Europe and Soviet Union (Routledge: London)

Soaita AM, 2010 Unregulated Housing Privatism PhD, King's College London

Soaita AM, 2013, "Romanian suburban housing: home improvement through ownerbuilding" Urban Studies, OnlineFirst, 1-18

Stanilov K, ed. 2007 The Post-Socialist City. Urban Form and Space Transformations in Central and Eastern Europe after Socialism (Springer: Dordrecht)

Struyk RJ, 1996 Economic Restructuring of the Former Soviet Bloc: The Case of Housing (The Urban Institute: Washington DC)

Sykora L, Bouzarovski S, 2012, "Multiple transformations: conceptualising the postcommunist urban transition" Urban Studies 49(1) 43-60

Szelenyi I, 1983 Urban Inequalities under State Socialism (Oxford University Press: Oxford)

Tsenkova S, 2009 Housing Policy Reforms in Post-Socialist Europe: Lost in Transition (Physica-Verlag: Heidelberg)

UNECE, 2001 Countries Profiles on the Housing Sector: Romania (Geneva: United Nations Economic Commission for Europe)

van Kempen R, Dekker K, Hall S, Tosics I, eds. 2005 Restructuring Large Housing Estates in Europe (The Policy Press: Bristol)

Yates J, 2012, "Housing Subsidies", in The SAGE Handbook of Housing Studies Eds. DF Clapham, WAV Clark, K Gibb (SAGE: London) pp 397-418 